together of the tsetse and trypanosomiasis research with the separate department of Experimental Tsetse Reclamation, which is in charge of Mr. Napier Bax.

E.A.F.R.O. (Fisheries) is at present quite small, dealing only with research on lakes and rivers. Its director is Mr. R. S. A. Beauchamp, who will have four or five scientific workers on his staff, and the headquarters are at Jinja in Uganda, at the point where the Nile originates from Lake Victoria. Capital expenditure of $£ 64,000$ and recurrent expenditure for five years of $£ 51,000$ are provided in whole from Colonial Development and Welfare Research funds. It is hoped that a fisheries research unit will soon be added for the marine waters of East Africa, and there is also recently established in Kenya a small station on the slopes of Mt. Kenya for investigating the special problems of streams and trout fisheries.

E.A.S.I.R.O. (Scientific and Industrial) will, it is hoped, be one of the most important of the research organisations, its subjects including buildings, roads, secondary industries, food processing and water pollution. Only a part of it yet exists, the East Africa Industrial Research Laboratory, situated in Nairobi, in charge of Mr. H. B. Stent. This organisation is intended ultimately to form a kind of local counterpart of the Department of Scientific and Industrial Research in Great Britain. Clearly, it will not be able to undertake extensive researches of a fundamental character except in special cases which demand proximity to local conditions. Wherever possible, problems arising in East Africa would be passed on to larger centres of research such as those established in Britain by the Department of Scientific and Industrial Research.

There are many scientific subjects of importance to Colonial development which are not covered by these research organisations. To mention a few : meteorology is looked after by the East African Meteorological Department, which includes research in its purview wherever it can be fitted in with the regular activities of recording and disseminating information. Hydrology is another subject of basic importance, and the beginnings of its study on a regional basis exist in a newly established hydrological survey of the Nile Basin within East Africa, necessary in connexion with the project for converting Lake Victoria into the largest reservoir in the world. Geology is still a function of territorial departments which, however, are coming into closer line with each other, aided by annual conferences which have been inaugurated in 1948. The same applies to work on the fauna, for which again annual meetings between game wardens have been started. There is much research progressing on insecticides with particular reference to their use against tsetse flies, this being the responsibility of the Colonial Insecticides Committee in London, which maintains a research unit in East Africa and is initiating a series of trials with aircraft in 1948. The problem of locusts is another subject on which research in East Africa is part of a wider service, in this case international in character. Archæology, in which East Africa has outstanding wealth, still awaits more extensive and more permanent facilities. Finally, there is great need for research on economics and statistics, and the East African Statistical Office, which, like the research organisations, is responsible to the East Africa High Commission, is already in existence and likely to expand.

\section{SCIENTIFIC ASPECTS OF COLONIAL DEVELOPMENT}

$\mathrm{T}$ FiE prasident of the British Association for the Advancement of Science, Sir Henry Tizard, referred in his inaugural address at the Brighton meeting to "our bounden duty, and the only certain way of safeguarding our future so long as we remain a large food-importing country, to develop our Colonial territories, particularly the under-populated African colonies, where the increase in population that would follow the control of disease and the increase of food supply would open fresh markets for international trade". The president of Section E (Geography) of the Association, Lord Rennell of Rodd, spэaking of "Geography as a Social Science, with special reference to Africa", said, "For our own good name, the social geographer must be called on to play his very large part in adapting our changing conceptions of African administration, and in se日king to rationalize the mess which western Europəan nations, including we ourselves, have made in the African continent". His address was followed by a discussion in Section $\mathbf{E}$ on the scientific aspэcts of colonial development, to which a number of the younger geographers, several with expərience of work and conditions in the Colonies, contributed. While recognizing that geography is only one of many sciences which could be, and must be, applied to the problems of the Colonies, the geographers were all agreed that their subject has a very definite and distinctive contribution, though one which has not hitherto been given adequate recognition by those in authority.

As to the nature of the contribution, there was considerable discussion. Some believed in the existence of a 'colonial geography', recognized, according to one speaker, by the governments and universities of all the Colonial Powers, except Great Britain, and particularly by France and the Netherlands: but a majority emphasized that colonial territories call for precisely the same type of geographical investigation as any other part of the world, and that the geographer's particular task is the study of the regional characteristics of different areas. Such a study requires the correlation of numerous branches of science, ranging from geology to social anthropology. One speaker recommended the formation of a single colonial institute, forming a part of one of the Universities of Oxford, Cambridge or London, which would not only be responsible for the training of administrative and technical officers for the Colonies but alse would undertake, or be cognizant of, colonial research in most, if not all, branches of knowledge. In an institute of this type, the geographer, with his interest in widely different aspects of environment and society, would have an important role. Another speaker suggested that in. sufficient use is made at present of the very considerable geographical knowledge of officials and others who have lived for long periods in the Colonies.

Lord Rennell described geography as "both the science and the art which deals with mankind on the earth on which we live". It studies in particular the interaction of physical facts on one hand, and economic, social and political conditions on the other. The influence of physical environment upon human activity is generally most noticeable among more backward people-though even here there is no such 
thing as 'environmental control'; and it is, therefore, particularly appropriate that geographers should concern themselves with tropical regions. Increasingly it is being recognized that the economic development of the tropics cannot come about except by the conquest of disease, the raising of standards of living, and the institution of comprehensive programmes of drainage and irrigation, road-building and port development. The blind belief in the inherent fertility of the tropies has at long last disappeared : and projects like the groundnut scheme in East Africa can succeed only after the most careful study of the facts of geology and topography, temperature and rainfall, natural vegetation and soil types. These facts are rightly studied by specialists-by geologists, meteorologists, plant ecologists, soil scientists, and the like. Too often, though, the interactions of these facts are inadequately considered, since they lie in the province of no particular specialist: and it is here that the geographer believes that he has a place in the scientific hierarchy, since by the nature of his training he is specially equipped to look out for interconnexions. $\mathrm{He}$ is not content with the facts of either geology or meteorology or botany, taken by themselves, in any particular area. He wants the complete picture-made up of physical conditions and human responses-or, as he puts it, the 'regional geography'.

The work of many of the economic and other missions to British Colonies in recent years would have been greatly facilitated if less time could have been spent in fact-finding, and more attention paid to the elaboration of concrete development programmes. Had the regional geography of British Colonies been studied as fully as that of, say, France -or even as inadequately as that of Great Britain itself-these missions would have had at least a basis on which to build. As it is, the regional geography of the Colonial Empire remains unwritten, apart from the isolated work of pioneers such as Clement Gillman in Tanganyika Territory. In this connexion the new colonial universities and colleges have an important contribution to make to our geographical knowledge of the world.

More than one speaker stressed the need for a colonial atlas, in the preparation of which geographers would take a prominent role: such an atlas would include distribution as well as topographical maps. The French and Dutch colonial atlases were quoted as excellent examples, and reference made to the successful efforts of Section $\mathbf{E}$ of the British Association in pushing forward the preparation of a National Atlas for Great Britain. It was suggested that as a first stage, maps might be prepared for groups of British territories, full use being made of the technique of mapping from air photographs and of the resources of the Directorate of Colonial Surveys.

Lord Rennell concluded by stating that facilities are now available for geographers to an extent nevier known before, and that the Colonial Office has recently asked specifically for trained geographers for research investigations in the Colonies. It is now open to geographers to make as effective a contribu. tion to the study of the problems of colonial development as they have made at home, through the Land Utilisation Survey and in other ways, to the problems of agriculture and of town and country planning. Their fellow-scientists will judge the validity of the geographers' claim by the quality of their work in the colonial field and by the distinetiveness of their contribution.

\section{NATURE OF INCENTIVES}

A S might have been expected, the discussion of A 'incentives' in the meeting at Brighton of Section J (Psychology) of the British Association afforded yet another opportunity for attempting to define the nature and extent of the responsibility of scientific workers for industrial efficiency. From various points of view, industry was challenged to try out new techniques and policies of management, and men of science were challenged to develop new concepts and procedures in the organisation of research.

Mr. Nigel Balchin, who opened the symposium, expanded his now well-known thesis that under present social conditions the traditional incentive of financial rewards has broken down, and that in future industry must rely upon entirely different motives for the maintenance of optimum effort. "If we have," he said, "on one hand a perfectly reasonable demand for a high material standard of life, which can only be supplied by productive effort, and on the other an equally reasonable demand for happiness in astivity, the only possible solution is to make work the happy activity." Since we do not yet know how this is to be done, the first responsibility of the man of science is to engage in research into basic principles. Psychologists should stop "trying to run other peoples factories' and concentrate on research into general principles.

The main themes of the second paper (that of the present writer) were in more than one way complementary to those of Mr. Balchin. There is, of course, much that we do not know; but, it was argued, there is also much that we know well enough but do not act upon. Research in this field, the results of which would be applicable, cannot be conducted entirely outside the factory but depends on close collaboration between scientific workers with more than a superficial knowledge of industrial administra. tion and managers with more than a superficial knowledge of scientific method. One field in which such collaboration would be especially fruitful, both in the application of existing knowledge and in the promotion of fresh research, is that of 'target setting' both on a national seale and in the detailed procedures of time and method study. Evidence of the ripeness of this particular harvest could be adduced from recent trends of thought in scientifically minded exponents of time-study procedures and from the increasingly open-minded and experimental mood of industry itself in this regard. Target, the monthly bulletin of production publicity of the Central Office of Information, is full of reports of new incentive experiments, the results of which should be well worth scientific observation and assessment.

Following up a point first made by Mr. Alec Rodger in the conference at Leamington of the Division for the Social and International Relations of Science of the British Association, it was further suggested that among the preconditions of the effective application of existing technical knowledge is the application of existing knowledge of another kind-of principles governing human relations in industry, on which there is a surprising unanimity of opinion among moral philosophers, political reformers and religious teachers of every school, party and sect. For example, the often quoted precept of Immanuel Kant that "every man should be treated as an end and not merely as a means" is one that in principle admits of translation into scientific terms and into 